\title{
Sola Fide: A Hermeneutical Approach
}

\author{
John Zizioulas
}

\section{Introduction}

The Reformation appeared as an event within the history of Western Christianity. The Eastern Churches were at that time pre-occupied with their own problems, trying to survive in the midst of external pressures from nonChristian secular powers and to safeguard their internal unity and faithfulness to their tradition. To the eyes of the Orthodox of that time, the Reformation was an exclusively Western affair about which, given the limitations of communication at that time and the information available, the interest in it was limited. Thus, when Melanchthon tried in 1559 to inform the Ecumenical Patriarch Joasaph II about the teaching of the Reformers by sending him a letter with a copy of the Augsburg Confession in Greek translation, he received no reply. It was only later, during the first patriarchal period of Jeremias II (1572-1579) and at the initiative of the Tübingen theological faculty, that a correspondence between Protestant and Orthodox theologians was initiated, but the whole enterprise was destined to become part of the confessional confrontations which forced the Orthodox to establish their own confessional identity vis-àvis Protestantism and Roman Catholicism. At the same time, the missionary zeal by which the above Western confessions tried to win over the Orthodox led the latter to an exclusivist and defensive attitude toward the former which still survives in some conservative Orthodox circles.

In such a polemical and apologetic context, in which each side tried to find reasons and arguments against the other, it was naturally difficult for the Orthodox to see and say anything positive about the Reformation. Today, for those at least who wish to liberate history from a deadly imprisonment to the past and open it up to the present and the future, it is not only possible but even natural and imperative to approach the Reformation in a more positive spirit. The Reformation was a movement and an attempt to listen and to respond to the Word and will of God, and as such it carries a message that still demands our attention and theological evaluation.

In the present paper, I shall try to look at the theological message of the Reformation by concentrating particularly on one of its fundamental claims: the prominence of faith in Christian existence. The principle sola fide, which 
constituted one of Luther's theological and spiritual axioms, carries an importance that transcends the polemical context in which it historically appeared. Sola fide must not be approached from the angle of what it denies (as an opposition to salvation through works and merit), but as a positive statement which carries in itself an existential significance. Fides is not one aspect of Christian existence, next or in opposition to another one; it is Christian existence itself. It is not faith and works, or faith without works, but works within faith. Luther himself is anxious to make it clear that, in stressing the priority of faith, he does not exclude the works but he wants to speak "of the good works of faith": "The fact of the matter is that I want very much to teach the real good works which spring from faith."1 Equally, we may imply, it is not faith and/or reason (the traditional scheme of medieval theology), but reason within faith. The term sola does not imply a rejection and an exclusiveness, but indicates the decisive factor without which all other factors lose their meaning - or, putting it positively, within (and only within) which they acquire their meaning. This is the challenge of sola fide that extends beyond the sixteenth century historical situation and calls for a hermeneutic that can give the Reformation an existential significance also for our time.

Luther was a Western theologian, and although he revolted against Scholasticism, he could not but be conditioned by it in his way of thinking. One of the hypothetical questions that come to one's mind is: what would the Reformation look like had the West and the East remained united as they were in the first millennium? Such a question acquires a crucial significance in our ecumenical context. For the essence of ecumenism is the willingness and the effort to recover a catholic ethos by which East and West can converse with each other in an attempt to make the Gospel relevant in our time. As an Orthodox, therefore, I cannot but put Luther's theology in the light of my own tradition. I propose, in particular, to raise the question of how Luther's sola fide principle would look if it were placed in the light of certain Greek patristic ideas relating to eschatology, anthropology and ecclesiology, and what philosophical implications can be derived from it. By so doing, I hope to offer some suggestions toward a hermeneutic of the Reformation in an existentially relevant theology.

1 Martin Luther, "Treatise on Good Works," in $L W 44$ (ed. B. Atkinson; trans. W.A. Lambert; Philadelphia: Fortress Press, 1966), 24. 


\section{Faith as Freedom: the Ontological Dimension of Faith}

Can God bring it about that what has been shall not have been? If, for example, it is firmly established that a virgin was corrupted, would it be impossible that she become again unspotted? This, as far as nature is concerned, is certainly true, and the judgement stands ... For contraries in one and the same subject cannot agree. This will further rightly be characterized as impossible if reference is made to the impotence of nature. Yet far be it that this be applied to the divine majesty. For He who gave nature its origin can, if He wishes, easily take away the necessity of nature. For He who rules over the created things does not stand under the laws of the Creator and He who created nature turns the natural order according to His own creative will. ${ }^{2}$

These provocative words of Peter Damian introduce us to the subject of faith as an ontological category. Faith is often understood in psychological terms. The sense of "trust" is regularly invoked to indicate its meaning. Such an approach to faith makes it easy to bypass the difficult problem that marked Western theology, particularly since its encounter with Greek philosophy: can faith be reconciled with reason? Can faith contradict the fundamental laws of nature and, therefore, of reason?

Ancient Greek philosophy, particularly since Aristotle's discussion of the idea of knowledge, enslaved the human mind to the logic of non-contradiction: in so far as something is, it cannot not be; in so far as we affirm, we cannot simultaneously deny. As stated by Aristotle: "The same attribute cannot at the same time belong and not belong to the same thing and in the same respect." ${ }^{3}$ Reality is a given that must be necessarily recognized and accepted, if it is to be known.

Ever since it encountered Hellenic philosophy, Christian theology was forced to wrestle with the problem of the relation between faith and reason. This became particularly acute since St. Augustine and during the entire period of the Middle Ages. The well-known phrases fides quaerens intellectum and credo ut intelligam, which were the basis of Anselm's reflections, indicate that understanding (reason) cannot be divorced from faith: the more you believe,

2 Peter Damian, De divina omnipotentia 10 (PL 145:611-12). Quoted by Étienne Gilson, L'esprit de la philosophie médiévale (Paris: Vrin, 1969), 358s.

3 Aristotle, Metaphysics 4,3. 1005b. 19-2o. 
the more you want to show it, or to convince yourself (and others) about it by appeal to reason. ${ }^{4}$

It lies beyond our purpose here to deal with the history of the subject of the relation of faith to reason in any detail. Suffice it to mention the position of Thomas Aquinas on the rights of reason in matters of faith, expressed in the following words: "Only that is excluded from the divine omnipotence which contradicts the reason or essence of being, that is, that something at the same time be and not be; and something that is of a similar nature is that something not have been that has been." Divine omnipotence stops at the threshold of reality, of what is already there. God cannot undo what God has done; God would not contradict the exigencies of nature which God freely created: God, "precisely because He is God, cannot act irrationally and contradict Himself." ${ }^{6}$ "That that which has been should not have been - with the contradiction that it implies - is not subject to the divine power." Even Duns Scotus, the passionate defender of divine omnipotence, could not go so far as to deny God the principle of non-contradiction: "the absolute omnipotence of God (potentia dei absoluta) applies to everything which does not involve contradiction." ${ }^{7}$

It is against this background of the struggle to reconcile faith with reason and make the former acceptable to the latter, that we must place and judge Luther's insistence on sola fide. Luther was not a philosopher in the sense of rational philosophy, and he openly rejected not only Aquinas but Aristotle himself. His sola fide and his tenebrae fidei, ubi nec lex, nec ratio lucet (the darkness of faith where neither law nor reason shines) ${ }^{8}$ seem to imply an open rejection of all philosophical thought. He avoided to speculate, and his insistence on the exclusiveness of faith was essentially a denial of the idea of salvation by works. The arguments he produced were based exclusively on Scripture (sola scriptura), and not on reason. Yet, this insistence on sola fide may itself involve or lead to a philosophy, perhaps against Luther's intentions. It is to such a philosophical significance of the Reformer's sola fide that I propose to comment in the lines that follow, bringing up at the same time the reasons why this theological principle did not lead to the overcoming of the dichotomy between faith and reason in Luther's theology.

The philosophical significance of sola fide lies in its import for ontology. Being was for Greek philosophy a datum. All reasoning springs from the recognition

$4 C f$. Gilson, L'esprit de la philosophie médiévale, $29 \mathrm{~s}$.

5 Thomas Aquinas, Summa Theologiae, I, q. 25, art. 2.

6 Frederick Charles Copleston, Aquinas (Middlesex: Penguin Books, 1955), 213.

7 Duns Scotus, Opus Oxoniense II, 17, n. 18.

8 LW 26:113-14 (Lectures on Galatians, 1535; on Gal 2:13). 
of what is already there, whether this is a general idea, in the Platonic way of thinking, or the concrete reality which is grasped by our senses, as Aristotle would prefer. From this basic assumption follow certain ontological principles. One is that human thought cannot undo or deny what is already there; being precedes our thought and whatever we do or say must correspond to what is already there. This leads to the absolute ontological sovereignty of the fact: whatever is done cannot be undone or denied.

Another principle that follows from this classical ontology is that of noncontradiction, to which we have already referred. What is already there (the fact) cannot be contradicted by its opposite. This is the logical consequence of the previous principle: since we cannot undo or deny a fact, we cannot contradict it by its opposite.

Both of these ontological principles were, as we have seen, adopted by Medieval scholasticism. Not even the omnipotent God can undo the past or contradict what is already there. The adoption of Aristotelianism by Aquinas and the application of being to the idea of God led to an ontology that bound God himself to the necessity of the "fact," making God unable to undo whatever is there and thereby contradict being. At the same time, as a result, human reason was enslaved to reality, forcing the intellect to adjust itself to what is already there: adaequatio rei et intellectus.

It was this kind of ontology that was implicitly attacked by the principle of sola fide. Luther, without intending to philosophize, shook the foundations of Greek and Scholastic ontology by writing in his commentary on the epistle to the Galatians:

[God] sent His Son into the world, heaped all the sins of all men upon Him [Jesus Christ], and said to Him: "Be Peter the denier; Paul the persecutor, blasphemer, and assaulter; David the adulterer; the sinner who ate the apple in Paradise; the thief on the cross. In short, be the person of all men, the one who has committed the sins of all men." ${ }^{\prime 9}$

Can the sins of the past be undone? Can what has already happened (a "fact") cease to exist? Luther does not operate with categories of ontology, but he nevertheless provokes the ontological question in our minds. He does not, of course, speak openly of the annihilation of the past realities (sins). Being conditioned by his Western (medieval) tradition of substitution, he prefers to transfer the past (to Christ), rather than annihilate it. Nevertheless, the removal itself of the past even by way of substitution is a scandal to Greek philosophy,

$9 \quad L W$ 26:280 (Lectures on Galatians 1535); on Gal 3:13. 
for it implies its annihilation with regard to a particular subject. And this is already a big step away from classical Greek and medieval ontology.

This direction is the right one because it is leading ontology towards its emancipation from the bondage of necessity, i.e. towards freedom. Greek ontology enslaved human being to the past, to facticity, to fate. In accepting and applying this ontology to theology, medieval scholasticism extended this enslavement to God himself. By stressing divine grace as a totally unconditional reality, Luther introduced freedom in its absolute sense into God's being. The way was already paved by St. Augustine in his fight against Pelagius, but it was forgotten in the meantime under the impact of ancient Greek thought on Christian theology. God had to be liberated from the bondage to the already existing, to facticity - a liberation that Luther applied not so much to God's being, or to being as such, as to God's acting, particularly with regard to sin and its forgiveness.

Luther is known for his sensitivity to the idea of freedom. He signed as Eleutherius in order to make this sensitivity apparent. His views on freedom, as expounded in his De servo arbitrio, give the impression that Luther is interested in the freedom of God rather than in human freedom. Leaving aside the disputed question whether Luther allows any freedom to the human being, or sacrifices it in fact for the sake of the freedom of God, we must take note of the association of sola fide with another principle: sola gratia. Sola fide and sola gratia are two sides of the same coin; they both point to freedom from the given, from the "fact." Grace, in its Pauline meaning recaptured by Luther, points to freedom as liberation from the fact of sin, a liberation that applies both to God and to the human being. The facticity of sin does not bind God's grace which can undo it, while the human being is free from the obligation to pay for it. What has been done is, thus, undone, and what has happened is non-existent.

We may call this the ontological scandal of grace, which is another form of the scandal of faith. But although this does imply a form of ontology, it does not tackle directly the problem of faith's relation to reason which has dominated Christian theology for centuries. Luther's preoccupation with freedom from sin (rather than from reality as such) did not allow him to work out a solution to the problem of the relation between faith and reason. This task was undertaken by a Lutheran theologian of a later time, Søren Kierkegaard. Building on Luther's sola fide, ${ }^{10}$ this philosopher drew the consequences from

10 Kierkegaard denies having read Luther's works, but the Reformer's influence on his thought, which came to him from his upbringing and education in a heavily Lutheran environment, must have been strong. 
it with regard to reason by proposing the idea of the absurd as the only alternative to faith. At about the same time, an Orthodox thinker, Fyodor Dostoevsky, being passionately concerned with the threat that reason presents to freedom, devotes almost his whole work to this subject. ${ }^{11}$ Renowned Protestant theologians, such as Karl Barth, rely on the Kierkegaardian logic of the paradox in dealing with faith and reason. Sola fide has proved to be seminal for philosophy, but the either/or relation between faith and reason still survives. A reason within faith is still an open challenge to theology and philosophy.

Luther's preoccupation with the problem of sin led him to put the emphasis on the cross as the decisive and, in a sense, the ultimate point in salvation. In The Bondage of the Will, Luther speaks of three lights which illuminate human existence: the light of nature, where reason and common sense suffice to solve many of the questions of everyday life; the light of grace, by which the revelation in Scripture gave humanity knowledge of God which was otherwise unattainable; and the light of glory, which belongs to the future, when the questions which Scripture has left unanswered will find their answers. ${ }^{12}$ Of these three lights it is, according to Luther, the second one that we must seek. It is in the theology of the cross that we find all that God wanted us to know. Seeking the theology of glory amounts to an attempt to know God as God is in himself by speculation or mystical experience, both of which are rejected by Luther, since God has revealed himself only in Christ and his cross. ${ }^{13}$

It is clear from this that Luther differs fundamentally from the Eastern tradition, which speaks a great deal about the vision of God "as God is," even of the vision of divine light, which the hesychastic tradition stresses so much. The notion of theosis, as developed in the East, appears to be incompatible with Luther's teaching.

11 The affinity of thought between Luther, Kierkegaard and Dostoevsky is brought up and discussed in depth by Lev Shestov. See his Athens and Jerusalem, ed. Ramona Fotiade and Bernard Martin, trans. Bernard Martin, 2nd ed. (Athens, OH: Ohio University Press, 2016); and Kierkegaard et la philosophie existentielle, 3rd ed. (Paris: Vrin, 20o6) esp. chap. 17.

12 Martin Luther, The Bondage of the Will, 1525, ed. and trans. O.R. Johnston and J.I. Packer (Grand Rapids: Fleming H. Revell Company, 1957). Cf. Brian Albert Gerrish, Grace and Reason. A Study in the Theology of Luther (Oxford: Clarendon Press, 1962), 171.

13 See Luther, First Disputation Against the Anomians [1537], quoted in Philip S Watson, Let God Be God! An Interpretation of the Theology of Martin Luther (London: Epworth Press, 1947), 95 . 
This, however, is not the only difficulty that the above position of Luther on eschatology presents. The belief that salvation is accomplished with the cross leaves us wonder about the importance of the resurrection for our salvation. The problem is twofold: a) is the overcoming of death a problem as serious for Luther as the forgiveness of sins? And $b$ ) does the view that all that is needed for our salvation is accomplished on the cross not orientate our existence towards the past rather than the future? Both of these questions relate to the way we understand faith.

With regard to the first question, Luther's position seems to imply that our faith is in a God who saves us from sin as from our most serious problem. There are indications in Luther's teaching of an anthropology which considers the soul as sufficient for the establishment of human identity, and, consequently, of an eschatology of the survival, judgment etc. of our souls. This may be traced to St. Augustine, who seems to speak of the future Kingdom as a place inhabited by souls, but it appears to be contrary to the teaching of St. Irenaeus and the Greek Fathers. There seems to be in Luther's teaching a dichotomy between the "outer" and the "inner" man based on an interpretation of the well-known Pauline distinction which the reformer understands in the following way: "Man has a twofold nature, a spiritual and a bodily one. According to the spiritual nature, which men refer to as the soul, he is called a spiritual, inner, or new man. According to the bodily nature, which men refer to as flesh, he is called a carnal, outward, or old man [...]."14 Might this imply that for Luther the restoration of the body through the resurrection is not as important as the cross for our salvation? I leave the answer to those who are more knowledgeable about Luther than myself.

With regard to the second question, namely the view that all that is needed for our salvation is to be found on the cross, does this not orient our faith towards the past rather than the future? The issue at stake is crucial for the definition of faith: what does faith consists in?

The most explicit definition of faith to be found in the Bible comes from the epistle to the Hebrews. In Heb 11:1, faith is defined as "the substance of things hoped for, the evidence of things not seen" (KJV). Continuing in the same chapter the author of the epistle refers to figures of the Old Testament who had accepted by faith the promises of God which would be realized in the future. The outstanding example is Abraham who, following God's call, undertook a

\footnotetext{
14 Martin Luther, Von der Freiheit eines Christenmenschen, in WA 7,21,12-15 ( $L W$ 31:344),

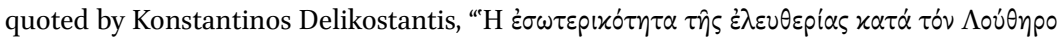

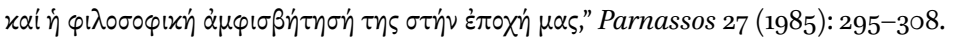


journey into the unknown ("not knowing where he was going"; 11:8, NRSV), to a place which would be shown to him in the future. Faith has an eschatological orientation; it is looking forward, not backward like Lot's wife. The futureoriented faith was developed by St. Maximus the Confessor in the 7 th century into an elaborate theology of the human being's call and destiny, which Adam refused to fulfill, thus turning the Fall essentially into a matter of faith.

Did the future orientation of the faith cease with the coming of Christ? Was the promise fulfilled and, instead of looking forward, we are now called to look backward to an accomplished and finished event? The question is no longer a rhetorical one if we consider what has actually happened to Christian theology in the current time. Faith has acquired the sense of our acceptance of truths (doctrines) formulated in the past or of the past events such as the Last Supper in the Eucharist conceived as an anamnesis of the past, which caused heated debates in the Reformation. The eschatological orientation has been restricted to the individual's fate after death, while the expectation of the Second Coming of Christ and the resurrection of the body have become so weak as to almost disappear from the faith of the believers.

The idea that the cross is the accomplishment and the highest point in God's saving acts appears to be biblical, especially in reading St. Paul's letters, but a careful examination of the biblical evidence shows that in the faith of the first Christian communities the acceptance of the kerygma of the resurrection was the prevailing one. The cross was undoubtedly at the heart of the apostolic kerygma, but it was followed and qualified by the resurrection. The Gospel contains a new promise to which faith is called to respond, namely that Christ will come again to raise us from the dead. In the Christian faith the abolishment of death is at least as important as the forgiveness of our sins. Putting the accent almost exclusively on the cross deprives faith of its eschatological orientation and makes it a matter of accepting an event of the past, of a fact verifiable by our senses. The definition of faith given in Heb 11:1 seems to point in a different direction.

Luther's staurocentric approach to sola fide seems to restrict the scope of faith to the destiny of humanity alone. It is, of course, true that only humans have faith, but the object and content of faith cannot be limited to the interests of humanity. Christ did not come to save only the human being, but the entire creation through humanity. "Creation itself will be set free from its bondage to decay and will obtain the freedom of the glory of the children of God" (Rom 8:21 NRSV). This is guaranteed by the resurrection and it concerns the future, the eschata. Faith, thus, turns humanity towards its cosmic destiny an idea we seem to miss in Luther. 
Accepting the principle sola fide does not mean for Luther that we exclude love: "a Christian is one who practices faith and love." Love is here equivalent to "works of love," and in this sense it must be understood as something not parallel to faith, or independent of it, but as deriving from faith, as existing within faith. ${ }^{15}$

Luther has been accused of acute individualism, even, by some, as the one who introduced individualism in Christian theology and life. ${ }^{16}$ The reason is precisely his insistence on sola fide: in making his decision of faith, the human being is absolutely alone before God. When Luther wants to explain what an individual is, he does so by pointing out that when you die, it is you who die, and no one else can do this for you. ${ }^{17}$ The individual is before God, stripped of all social attributes, abstracted, as a dying person is abstracted from all his social relations.

Faith is a decision, a choice between God and what is not God, and decisions can be made only by an individual. This conception of faith is extended to its ultimate philosophical consequences - no doubt under Lutheran influence by Kierkegaard, who describes existence in terms of either/or choices leading to impasses, paradoxes and absurdities for rationality and ethics. Abraham, the father of faith, is presented in Fear and Trembling as the individual par excellence, who does not speak about his decision to sacrifice Isaac even to his closest relatives, precisely because the act of faith must not be communicated to and shared by others, so that it may not fall under the category of the "general" which is inevitable in all language and communication. Abraham decides and acts alone - this is what faith requires.

Underneath Luther's individualism lies an anthropology of the thinking subject which may be traced back to St. Augustine. This great thinker is the first one in the history of Christian theology who writes Confessions, by which he turns himself into the depth of his soul and addresses God by way of selfexamination and introspection. Luther, an Augustinian by formation, similarly operates with an anthropology of the "inner man" whom he identifies with the human soul in which he locates the decision of faith. The soul is the most individual characteristic of human being, since no one else can claim it and, most importantly, since it survives death: "the soul lives also well without a

\footnotetext{
15 See note 1 , above.

16 Thus Alasdair C. MacIntyre, A Short History of Ethics, 2nd ed. (London: Routledge, 1998), $117-18$.

17 MacIntyre, $A$ Short History of Ethics, 121.
} 
body" and will give account to God for one's earthly life in the future judgment. As Konstantinos Delikostantis has pointed out, it is in the light of the distinction between the "outer" (body) and the "inner" (soul) man that we can also understand Luther's idea of human freedom: the human being is made free by the word of God who addresses the inner man, i.e. his soul. ${ }^{18}$ Individualism and psychocentrism in Luther's anthropology explain why faith for him is a decision that each one is called to make alone before God.

All this takes us to the consideration of a major problem that I have tried to discuss elsewhere (in my Being as Communion): is the notion of "individual" the same as that of person? Luther seems to think that it is. In one of his references to this term, he relates it to faith by calling it its result: "Fides [...] facit personam."19 Given that, as we have already noted, faith is a decision that we can make only by standing alone before God, "person" and "individual" must be identical in Luther's mind. This identification of the two terms would be a natural one for a Western theologian, since it had become common in the West from the time of Boethius' definition of person as individua substantia naturae rationabilis. But whereas for fathers such as St. Augustine (and, of course, the Cappadocians) the term persona was a relational category which would exclude any isolation in one's existence, it does not seem to be so for Luther, at least with regard to faith.

The problem, therefore, with which Luther leaves us with regard to faith is how to accommodate it in an understanding of personhood as a relational category, which means finally how to make it an integral part of ecclesiology. There is in Luther's teaching an extensive treatment of the Church, and it would be unfair to disregard or dismiss his use of the idea of communio in his ecclesiology. His ecclesiology is marked heavily by Pneumatology, and he takes a position against isolation when he asserts that the Spirit is the one who saves from isolation and leads to communion and the diakonia of the others. ${ }^{20}$ How can this ecclesiology of communion be reconciled with the individualistic approach to faith as expounded above?

18 See note 14 above.

19 Die Zirkulardisputation de veste nuptiale (1537), WA 39/1:283,16. As Eberhard Jüngel remarks, this is meant by Luther as a rejection of a long tradition going back to Aristotle's Nichomachean Ethics, according to which we become just by doing just acts: opus non facit personam; quod persona sit facta per fidem a Deo, Luther claims. See Eberhard Jüngel, Justification: The Heart of the Christian Faith. A Theological Study with an Ecumenical Purpose, trans. Jeffrey F. Cayzer (Edinburgh: T\&T Clark, 2001), 247.

20 See e.g. his "Large Catechism," in Theodore G. Tappert, ed., The Book of Concord. The Confessions of the Evangelical Lutheran Church, trans. Theodore G. Tappert (Philadelphia: Fortress Press, 1959), 415-18. 
I am not sure I have the answer to this question, as I am not a specialist of Luther. In trying to relate Luther to my own tradition, I can only state that since none of us exists or can exist in isolation from the others, faith itself can operate only relationally. Faith does not precede communion; it takes place within it. Faith is a gift of the Spirit through the Church. We can say "I believe" only as part of "We believe" (the original form of the baptismal creeds was in the first-person plural). Any act of faith that does not involve simultaneously communion is not genuinely Christian faith. In confessing Christ, we confess at the same time the Church.

Here lies, perhaps, a problem or a difficulty: can Christ be so closely (ontologically) united with the Church that he would be inconceivable without it? I fear that the Reformation, either because it had to fight and correct the excessive ecclesiocentricism of Rome, or because it had inherited from Scholasticism a priority of Christology in relation to Pneumatology (cf. the filioque), was led to a sharp distinction between faith in Christ (which could be individual) and belonging to the Church in the Spirit (which would be personal-relational). There is a strong Christocentric mysticism in Luther, but it is tied up with the individual's forgiveness of his or her sins. ${ }^{21}$

\section{Conclusion}

I have tried to offer some personal remarks on the significance of Luther's sola fide and its bearing upon the encounter of the Reformation theology with my own tradition, as I understand it, with regard to the subject of faith. Luther's principle of sola fide is full of significant implications for theology and Christian existence. If extracted from the polemical and apologetical context in which it appeared historically, this principle raises questions that continue to be relevant for our time, not only within our ecumenical discussions but also for our existential approach to the Gospel.

With this principle, Luther liberated God from the bondage to reason and to facticity to which God is enslaved by our common sense rationality, thus raising freedom to its absolute and unconditional character. God can not only do, but also undo things, particularly the facts of human sins, by transferring them

21 See for example, how Luther comments on John 6:56, in Sermons on the Gospel of John, $L W$ 23:144s: "Now this is a precious dwelling place [...] that through faith in Christ and through our eating we, poor sinners, have Him abiding in us [...]. But now since you have received forgiveness of sins you are not worried about the devil." 
to his Son and annihilating them on the cross. Faith in God means, therefore, faith in the crucified Christ.

This extreme stauro-centricity, we observed, raises questions about the importance of the resurrection, both of Christ and of ourselves, in the eschaton and ultimately for the divine economy as a whole. Faith as promise, which is also an idea of the Reformation, should not stop with the acceptance of the cross and acquire only the significance of the revelation of what was accomplished at Golgotha. The eschatological significance of faith as an orientation to a future that will add something new, different and important, particularly through the abolition of death and the resurrection of the body, is at least as important for our existence as the remission of our sins.

Finally, we have noted that the ecclesiological dimension of faith is present in Luther's theology in the form of communio sanctorum as the society of the true believers. The faith of the individual is the prerequisite of belonging to the communion of the Spirit; the individual precedes the community. Faith occurs primarily at the level of the "I," and culminates in the "we." This raises the question of the relation between Christology and Pneumatology as a central one in ecumenical theology. It also brings up the anthropological question of the relation between the notions of "individual" and "person." A hermeneutic of Luther's theology would demand placing his thought in the light of these questions.

\section{References}

Copleston, Frederick Charles. Aquinas. Middlesex: Penguin Books, 1955.

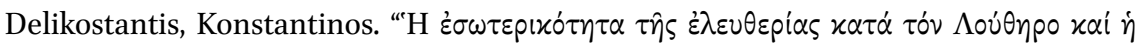

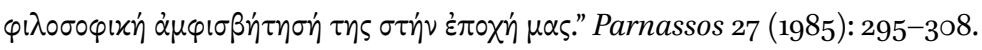

Gerrish, Brian Albert. Grace and Reason. A Study in the Theology of Luther. Oxford: Clarendon Press, 1962.

Gilson, Étienne. L'esprit de la philosophie médiévale. Paris: Vrin, 1969.

Jüngel, Eberhard. Justification: The Heart of the Christian Faith. A Theological Study with an Ecumenical Purpose. Translated by Jeffrey F. Cayzer. Edinburgh: T\&T Clark, 2001.

Luther, Martin. The Bondage of the Will, 1525. Edited and translated by O.R. Johnston and J.I. Packer. Grand Rapids: Fleming H. Revell Company, 1957.

MacIntyre, Alasdair C. A Short History of Ethics. 2nd ed. London: Routledge, 1998.

Shestov, Lev. Athens and Jerusalem. Edited by Ramona Fotiade and Bernard Martin. Translated by Bernard Martin. 2nd ed. Athens, OH: Ohio University Press, 2016. Shestov, Lev. Kierkegaard et la philosophie existentielle. 3rd ed. Paris: Vrin, 2006. 
Tappert, Theodore G., ed. The Book of Concord. The Confessions of the Evangelical Lutheran Church. Translated by Theodore G. Tappert. Philadelphia: Fortress Press, 1959.

Watson, Philip S. Let God Be God! An Interpretation of the Theology of Martin Luther. London: Epworth Press, 1947. 